\title{
Communication Transparency in Ethical and Traditional Banking in Spain
}

\author{
Elisa Baraibar-Diez ${ }^{1}$, María D. Odriozola ${ }^{2}$, José Luis Fernández Sánchez ${ }^{3}$ \\ ${ }^{1}$ Lecturer of Business Administration, Business Administration Department, University of Cantabria, Spain \\ ${ }^{2}$ Lecturer of Business Administration, Business Administration Department, University of Cantabria, Spain \\ ${ }^{3}$ Lecturer of Business Administration, Business Administration Department, University of Cantabria, Spain
}

\begin{tabular}{|c|c|}
\hline & ABSTRACT \\
\hline $\begin{array}{l}2017 \text { Research Leap/Inovatus Services Ltd. } \\
\text { All rights reserved. }\end{array}$ & $\begin{array}{l}\text { Transparency is a key value in the thinking of ethical banks, but do they perform different } \\
\text { practices over traditional banking that justify or support that commitment to transparency? This } \\
\text { study examines transparency in the communication process in two different types of banking in }\end{array}$ \\
\hline $\begin{array}{l}\text { DOI: } 10.18775 / \text { jibrm.1849-8558.2015.22.3004 } \\
\text { URL: } \underline{\text { http://dx.doi.org/10.18775/jibrm.1849- }} \\
\text { 8558.2015.22.3004 }\end{array}$ & $\begin{array}{l}\text { Spain: ethical/alternative banking and traditional banking. The identification of an explicit } \\
\text { commitment to transparency, the analysis of disclosed information, the identification of } \\
\text { information channels and the identification of stakeholders allow assessing transparency, which }\end{array}$ \\
\hline $\begin{array}{l}\text { Keywords: } \\
\text { Transparency, } \\
\text { Communication, } \\
\text { Ethical banking, } \\
\text { Traditional banking, }\end{array}$ & $\begin{array}{l}\text { actions developed to achieve a greater transparency level, where the resources of the financial } \\
\text { institution seem to prevail over the thinking of the organization. This exploratory study will } \\
\text { contribute to the knowledge about ESG information disclosure in the banking industry, } \\
\text { developing the identification of practices that improve transparency and will result in greater } \\
\text { efficiency in decision-making processes. }\end{array}$ \\
\hline
\end{tabular}

New business models

\section{Introduction}

The field of ethics in finance is being recently given more attention (Cowton 2002; Cowton 2010), but the truth is that few articles focus on analyzing the differences between traditional and ethical banks (San-Jose et al. 2011) and even less from the point of view of communication (Gutiérrez \& Sádaba 2010) and more especially, transparency (San-Jose \& Retolaza 2008).

Communication is considered by the academic literature as a strategic management tool (Gutiérrez \& Sádaba 2010) since communication "shapes meaning, builds trust, creates reputation, and manages symbolic relationships with internal and external stakeholders in order to support organizational growth and secure the freedom to operate" (Zerfass \& Huck 2007: 108, cited by Gutiérrez \& Sábada 2010). Within the field of communication, CSR communication has emerged as a response to the communicative challenge of CSR to gain and maintain legitimacy (Schoeneborn \& Trittin 2013). These authors classify research on CSR communication, which is affected by several types of studies including studies from corporate communication, public relations, organization, and management studies. They also describe two different views regarding communication: the transmission view, which represents communication primarily as "the channel through which information or messages are transported from a sender to a receiver" (Shannon \& Weaver 1949, cited by Schoeneborn \& Trittin 2013) and the constitutive view, where "CSR communication is simply one of many communicative practices that collectively constitute the phenomenon we call organization" (Schoeneborn \& Trittin 2013: 198); and finally develop the communication constitutes organizations (CCO) perspective, which argues that "organizations essentially consist of communication" (Ashcraft et al. 2009, cited by Schoeneborn \& Trittin 2013) and result from the interactions among the internal and external stakeholders. By applying this theoretical approach to the field of CSR communication, Schoeneborn and Trittin (2013) identify four aspects of the CCO perspective applied to CSR communication: connection of CSR practices with other organizational practices, talk can be an action, extension of CSR by involving third parties, and responsibility of non-human agents in CSR communication. We consider that those aspects are interesting to be included in the analysis of CSR communication transparency between traditional and ethical banking.

The potential for exploring CSR communication from the point of view of transparency opens a new line of research, developing how to deal or integrate previous approaches with the concept of transparency. The aim of this analysis is to explore transparency in communication by comparing CSR communication in traditional banking and ethical banking. Since this latter type of banking includes transparency as an intrinsic corporate value, it is interesting to know whether ethical banks implement distinguishing CSR communicating practices. In this sense, this study relies on traditional key elements of CSR communication, such as objectives and channels, but includes the concept of transparency as integration of all the elements of business communication: issuer, message, channel, and receiver.

This study is relevant for several reasons. Firstly, we contribute to the literature on CSR communication by integrating the concept of transparency, which is essential to achieve effectiveness. Our assumption 
is not to analyze CSR strategies within the companies in the sample, but the analysis is embedded in the conceptual framework of CSR communication proposed by Du et al. (2010), and the assumptions of Schoeneborn and Trittin (2013) and their CCO view. Thirdly, previous studies about ethical banking have been focused on one initiative or bank and comparative analysis between ethical and traditional banking have not been focused on CSR or CSR communication but we believe that the banking sector represents a unique opportunity since almost no other sector have such a clear dichotomy between ethical businesses and traditional businesses, allowing academics to compare whether ethical banking implements different actions in order to obtain a more effective CSR communication.

The structure of this paper is organized as follows. Next section provides an overview of traditional and ethical banking, describing the characteristics of this special type of banking. The third section shows different frameworks of CSR communication described from the perspective of transparency. This is followed by the case of the banking industry in Spain, where two traditional banks and two ethical banks have been analyzed. The paper concludes with a discussion.

\section{Traditional banking and ethical banking}

Although there is no commonly accepted definition, ethical banking can be defined as "the activity which is developed by formal and informal financial intermediaries under the principles of transparency and democratic organization, whose primary objective is to contribute to sustainable socioeconomic development" (De la Cuesta et al. 2006). Otherwise, some other authors require that the institutions must be recognized "as a bank or as a credit institution by national authorities to be considered ethical banks" (San-Jose et al. 2011: 152).

The principles of participatory democracy and transparency not only in the effectiveness of the bank but in the destination of investments / placement of assets; the consideration of credit as a right for anyone; the obtaining of social profitability; the commitment to society, or the contribution to the reduction of poverty, financial, and social exclusion and inequality are some of the common characteristics of ethical banks (De la Cuesta et al. 2006; San-Jose et al. 2011; febea 2012). Although traditional banking has developed the concept of Socially Responsible Investment (SRI) and implements socially responsible activities which could be related to characteristics of ethical banking, it is not considered as ethical banking.

De la Cuesta et al. (2006) describe different ethical banking initiatives in developing countries, the Islamic Banking or the occidental concept of ethical banking, which is usually related to the concept of Socially Responsible Investment (SRI). They also classify European ethical banking initiatives in three types: ethical banking based on environment, social, educational, and cultural principles; ethical banking targeted to support to third sector organizations or non-lucrative projects, and interest-free ethical banking. In the last few years, different networks have been raised to promote an alternative financial system, different from the current system. In this sense, the Global Alliance for Banking on Values (GABV) - founded in 2009 - is "an independent network of banks using finance to deliver sustainable development for not served people, communities, and the environment" (GABV 2015) and comprises 28 financial institutions operating across 31 countries. In Europe, the European Federation of Ethical and Alternative Banks (FEBEA Fédération Européene des banques Ethiques et Alternatives), founded in 2001 , is a nonprofit organization incorporated under Belgian law that "aims to create financial tools able to help existing European initiatives" and encourages "the growth of new initiatives in the field of alternative finance" (febea 2015). It comprises 11 banks, 6 savings and loan cooperatives, 5 investment companies and 3 foundations (Febea; 2015).

Both the portion of assets on the balance sheet devoted to lending and a number of client deposits reflect the degree to which a bank finances the real economy (GABV 2014). The report Real Economy - Real Returns: The Business Case for Sustainability Focused Banking developed by GABV in 2014 states that for sustainability focused banks - SFBs -, the level of lending in 2013 was nearly doubled (76.2\%) the level of lending of the Global Systemically Important Financial Institutions - GSIFIs (40.5\%) and also SFBs rely much more on client deposits to fund their balance sheets $(80.4 \%)$ in comparison with GSIFIs (48.8\%). Table 1 shows growth rates from 2003-2013 and 2009-2013 in loans, deposits, assets, equity and total income. SFBs had higher growth in all variables, especially in the period after the crisis, which could respond to a change of mentality in society after instability in recent years.

The question of whether ethical Banks are different from traditional banks has been raised by San-Jose et al. (2011), obtaining evidence, in a sample of 114 European banks, that placement of assets and transparency of information are features that differentiate ethical banking from other financial institutions. They consider that "the transparency variable marks the first and the foremost important difference between credit institutions" (San-Jose et al., 2011: 156), using a score of five values to show the different levels of information.

Table 1: Growth (Compound Annual Growth Rates) in loans, deposits, assets, equity and total income in GSIFIs and SFBs.

\begin{tabular}{llll}
\hline Variable & Banks & $2009-2013$ & $2003-2013$ \\
\hline \multirow{2}{*}{ Loans } & SFBs & $13.2 \%$ & $9.3 \%$ \\
& GSIFIs & $3.8 \%$ & $8.3 \%$ \\
Deposits & SFBs & $15.3 \%$ & $10.4 \%$ \\
& GSIFIs & $4.9 \%$ & $9.4 \%$ \\
Assets & SFBs & $12.9 \%$ & $9.0 \%$ \\
& GSIFIs & $0.7 \%$ & $8.5 \%$ \\
Equity & SFBs & $13.8 \%$ & $10.8 \%$ \\
Total & GSIFIs & $8.6 \%$ & $11.0 \%$ \\
Income & SFBs & $8.5 \%$ & $6.4 \%$ \\
\hline
\end{tabular}

Note: GSIFIs: Global Systemically Important Financial Institutions. SFBs: SustainabilityFocused Banks.

Source: Real Economy - Real Returns: The Business Case for Sustainability Focused Banking (p. 5). GABV (2015)

\section{CSR communication and transparency}

In the last few years, the conceptual framework of CSR has been applied to CSR communication, and several authors emphasize that CSR communication "aims to provide information that legitimizes an organization's behavior by trying to influence stakeholders' and society's image of the company" (Birth et al. 2008). When, in most cases, implementing a CSR strategy is not a differentiator element within the industry, companies' social responsibility communication should go further CSR disclosure and CSR reporting - reporting is a way of disclosure - and should try to manage information so that it reflects an engagement with stakeholders.

In fact, there are recent studies implemented with real stakeholders that revealed that awareness of a company's CSR activities among its external and even internal stakeholders is typically low (Du et al. 2010), which shows a lack of efficiency when it comes to reaching the receiver of 
information (Baraibar-Diez \& Luna 2012) and results in lower returns for the company. That is why the growing skepticism of corporate communication needs to be alleviated by the proper communication of CSR activities (Birth et al. 2008; Du et al. 2010). To do this, most of agents agree that one of the key elements to success is transparency (Carroll 1999; Birth et al. 2008; Baraibar-Diez \& Luna 2012; BaraibarDiez \& Odriozola 2015). Otherwise, the nature of CSR information qualitative information, heterogeneous information, voluntary information, more potential audiences - makes it really difficult to assess transparency.

Birth et al. (2007) consider that the "intrinsic problems encountered in achieving transparent CSR communication can be overcome by developing an appropriate definition of the communication objectives and channels as well as by understanding the communication context". We agree with this statement but we consider that objectives, context, and channels are not enough if the company does not commit to a transparent strategy, identifies their stakeholders - which are the key to disclose specific information through a specific channel of information - and commits to disclosure one step beyond simple dissemination of information

Transparency can be understood as the integration or coherence between all the elements of business communication (Baraibar-Diez \& Luna 2012; Baraibar-Diez \& Odriozola 2015). In this contribution, contextualization of transparency is based on traditional communication models, such as the mathematical model proposed by Shannon and Weaver in 1949 or especially the SCMR model proposed by Berlo in 1960. Considering the CSR frameworks proposed by Du et al. (2010) and Schoeneborn and Trittin (2013), the approach here will pay attention on how to reinterpret those CSR frameworks through the prism of transparency and the elements of traditional communication - issuer, channel, message, and receiver - focused on the banking sector.

\section{Issuer}

San-Jose et al. (2011) describe three different theories to explain the theoretical foundation of ethical banking around the concepts of integrity (responsibility to prevent exclusion), responsibility (negative criteria for investments) and affinity (positive criteria in investment): Social Institutional Theory, CSR, and Property Right Theory. Whilst the first theory considers that ethical banking might be an instrument of Public Authorities to "mitigate the disruptions of the banking system" and the Property Right Theory explains "ethical banking as decisions taken by bank owners", CSR theory allows describing ethical banking as a type of differentiated bank seeking to achieve an ethical maximum integrating ethical aspects into the organization (San-Jose et al., 2011).

Regarding transparency, commitment of bank managers is essential to establish a relationship of trust with stakeholders, which should be materialized in the principles or ideology of the bank. In this sense, they should establish generic communication practices and appropriately define the objectives of CSR communication, which have to be described according to emerging issues and certain stakeholders (Birth et al., 2008). In this sense, the connection of CSR practices and CSR disclosure with other organizational practices affect trust and confidence among stakeholders, determining how they perceive and interact with the organization and resulting in two types of organizations: harmonic and polyphonic.

\section{Channel}

When issuing CSR communication, companies may use a wide range of channels, including "annual social reports, thematic reports, codes of conduct, a dedicate section of its official corporate website to CSR, stakeholder consultations, internal channels, prizes and events, causerelated marketing, product packaging, press releases, TV commercials, and points of sale" (CSR Europe 2000a,b, cited by Birth et al. 2008; Du et al. 2010). While the binomial message-stakeholder (that is, identifying the interests of each group of interest) is further more developed, the integration of the channel of communication to that pairing is underdeveloped.

Reports, magazines, and newsletters disclosed by the company are considered traditional media (Berceruelo et al. 2013) and official documents on which the company takes the initiative of communication (not the website, where the initiative is held by the receiver who access the site). Social reports (CSR reports, Sustainability reports) play a prominent role (Birth et al. 2008) and have become the most widely used format to communicate CSR information. The possibility of standardization, certification, and audit of those reports enhances corporate credibility. Although the reporting rate in Europe barely increased, there is an overall upward trend (KPMG International Survey of Corporate Responsibility Reporting 2013). In Spain, otherwise, the rate of corporate responsibility reporting decreased from 88 in 2011 to 81 in 2013. KPMG explains that "mergers and acquisitions among big firms in the banking sector have resulted in smaller companies, which are less likely to issue CR reports, being included in the Spanish N100" (KPMG International Survey of Corporate Responsibility Reporting 2013: 23).

The emergence of new technologies, the Internet and social networks also offer new formats of communication with target audiences, allowing companies to use a bidirectional communication (for instance, apps, forums, blogs...). Although the adoption of social media has been relatively slow in the finance sector, companies have begun to understand the potential of this platform to build communications and marketing strategies around (Jackson 2012). Brand damage, reputational crisis due to speed and volume of information, lack of understanding and lack of time and resources are some of the concerns companies have to deal with regarding social media (Jackson 2012).

Finally, companies should consider that their stakeholders serves as channels of communication to reach other stakeholders. Employees and consumers can be CSR communicators (Dawkins 2004; Du et al. 2010) and companies should find ways to involve them and try to convert them into CSR advocates, promoting CSR activities too.

\section{Message}

Du et al. (2010) describe factors that companies can emphasize in their CSR communication such as "its commitment to a cause, the impact it has on the cause, why it engages in particular social initiatives, and the congruity between the cause and the company's business" (Du et al., 2010: 11). The fact is that the content of environmental, social and governance (ESG) information is an important field of research, but from the point of view of transparency, content or volume of information lose importance in favor of other characteristics of information such as materiality, timelines of information or trustworthiness, which are harder features to achieve.

Standards in CSR communication are the best way to homogenize CSR information. In this sense, Global Reporting Initiative (GRI) is the leading reporting framework, playing "an important role in improving consistency in CSR reporting and the quality of disclosure" (KPMG International Survey of Corporate Responsibility Reporting 2013: 30), but there are other initiatives such as the recent ISO26000 or the Integrated Reporting. When certifying the accuracy of content, it is possible for companies to issue a statement of independent verification or 
follow the standards issued by AccountAbility (AA1000E, AA1000ES or AA1000APS) or ISAE 3000. Zorio et al. (2012) consider that assurance of Sustainability and CSR reports is "a valuable voluntary tool to provide stakeholders with higher credibility" (Zorio et al., 2012: 484), founding different perceptions of credibility depending on the CSR assurance undertaken.

\section{Receiver}

The stakeholder relationship management approach describes "how to manage relationships with various stakeholders in line with company's values, principles, and mission" (Gutiérrez \& Sádaba 2010: 181). There are several classifications of stakeholders: primary and secondary stakeholders (Clarkson 1995; Kaptein \& van Tulder 2003), shareholder and non-shareholders (Schrenk 2006), internal and external stakeholders (Freeman \& McVea 2001) or, as pointed out by Mitchell et al. (1997), the owner of the capital or less tangible assets owners, investors and not investors, or resource providers or employees of the company. In the financial sector, specific attention is paid to three types of stakeholders: shareholders, clients, and employees, although most used classification is made between internal groups (employees) and external groups (customers, suppliers, shareholders, environment, society, potential investors, brokers, financial analysts, rating agencies, regulators, unions, media...).

Du et al. (2010) include the classification of stakeholders developed by Dawkins (2004) into opinion-leader audiences (for instance business press, investors, and NGOs) and the general public (consumers and local communities. Dawkins (2004) describes that the first group is more likely to proactively seek out CSR issues (focused on the business impact of CSR issues in the case of investors) and the second group is aware of CSR issues through independent channels.

Du et al. (2010: 15) reflect that "different audiences vary in terms of their expectations of businesses and in information needs, and may respond differently to the various communication channels of CSR". Thus, the better the company identifies and describes its relationships with its stakeholders, the more efficient those relationships will be. In this sense, it is important to analyze the objectives addressed to every type of stakeholder. Birth et al. (2008) describe the objectives that characterize CSR communication addressed to clients, employees, and shareholders (see Table 2).

Table 2: Objectives and stakeholders.

\begin{tabular}{ll}
\hline Stakeholders & Objectives \\
\hline Clients & $\begin{array}{l}\text { Reputation, product differentiation, customer } \\
\text { loyalty } \\
\text { Employees }\end{array}$ \\
& $\begin{array}{l}\text { Publicity and good reputation; increase employee's } \\
\text { the company as a future employer; reduce employee } \\
\text { turnover } \\
\text { Shareholders } \\
\text { Awareness that the company represents an actual } \\
\text { opportunity for investing in a socially responsible } \\
\text { way. Communicating the tangible advantages of the } \\
\text { company's CSR strategy. }\end{array}$ \\
\hline & \multicolumn{2}{c}{ Source: Birth et al. (2008) }
\end{tabular}

The analysis process is based on the framework based on the traditional elements of communication described in the previous section. In order to facilitate the reader's understanding of this framework, Table 3 shows a summary of the main core issues identified in each of the elements. This summary serves as a guide - in the same way, that the questions are preset in a structured interview - to assess those CSR communication and transparency issues in the case applied to the dichotomy of the banking sector in Spain. This process will provide us knowledge and initial understanding of the problem and will be useful when establishing future research hypotheses.

Table 3: Integration of CSR frameworks from the point of view of transparency

\begin{tabular}{ll}
\hline Element & Framework proposed \\
\hline Issuer & Commitment to transparency (mission, vision, corporate \\
& values) \\
& Objectives should be defined in line with emerging \\
& issues and corresponding stakeholders (Birth et al. 2007) \\
& Harmony vs. polyphony. Consonance of CSR \\
& communication practices with other organizational \\
& communication practices (Schoeneborn and Trittin, \\
& 2013). \\
& Talk can be action (Schoeneborn and Trittin, 2013) \\
& Third parties involvement (Schoeneborn and Trittin, \\
& 2013) \\
& Scope of agency and responsibility (Schoeneborn and \\
& Trittin, 2013) \\
& Corporate reputation and CSR positioning (Du et al., \\
& 2010) \\
Official documents (annual CR report, press releases, \\
section of website) \\
Advertising \\
Product packaging \\
Word-of-mouth by stakeholders \\
Controllability vs credibility. \\
Materiality \\
CSR standards \\
CSR commitment, CSR impact, CSR motives, CSR fit \\
(Du et al., 2010) \\
Identification of stakeholders \\
Stakeholder type, Issue support, Social value orientation \\
(Du et al., 2010)) \\
Receiver
\end{tabular}

Source: Authors from Birth et al. (2008), Du et al. (2010), Schoeneborn and Trittin (2013)

\section{The case of traditional banking and ethical banking in Spain}

In March 2015, there were 317 Monetary Financial Institutions (MFIs) operating in Spain: 1 Central Bank, 219 Credit Institutions, 45 Money Market Funds and 52 other institutions (European Central Bank, 2015). To analyze the communication of the banking sector is important for some reasons, such as the homogenization of supply, the increasing competitiveness (Gutiérrez and Sádaba 2010) or a banking customer with higher financial culture (Cortés 2003). Moreover, any other sector provides such a clear dichotomy between traditional banking and ethical banking, allowing to analyze whether there are unique or distinctive CSR communication practices in line with the principles of ethical banking.

\section{Methodology}

"Research in any field begins with curiosity" (Stebbins, 2001). This study is exploratory in nature, with the aim to better understand the differences between traditional and ethical banking regarding transparency in CSR communication. Methodology in exploratory studies is not as rigorous as in conclusive studies and sample sizes may be smaller (Nargundkar 2003). Information for this exploratory research was sourced from CSR or sustainability 2014 reports and Spanish corporate websites (accessed May 2015).

\section{Sample}

In line with exploratory analysis, a purposive sampling technique has been chosen to select the elements of the sample. Specifically, we have considered designing an expert sampling, where "the sample recruitment process is to identify all those who have the most extensive expertise in a specific area of knowledge" (Trotter, 2012). In this sense, we can consider 
selected banks as experts in the fields of traditional and ethical banking, representing "the vast majority of their subject area" (Romney et al., 1986, cited by Trotter, 2012: 399). Thus, according to the 2014 update of the list of global systemically important banks (G-SIBs) issued by Financial Stability Board, we have selected the two G-SIBs Spanish banks: Santander and BBVA. From the Sustainability Focused Banks that are part of the Global Alliance for Banking on Values, two banks operating in Spain have been considered: Banca Popolare Etica (which is called Fiare in Spain) and Triodos Bank.

Table 4: Sample of banks

\begin{tabular}{|c|c|c|c|c|}
\hline Entity & $\begin{array}{l}\text { Santander } \\
\text { www.sant } \\
\underline{\text { ander.com }}\end{array}$ & $\begin{array}{l}\text { BBVA } \\
\text { www.bbva } \\
\underline{\text { com }}\end{array}$ & $\begin{array}{l}\text { Triodos } \\
\text { Bank } \\
\text { www.triod } \\
\underline{\text { os.es }}\end{array}$ & $\begin{array}{l}\text { Banca } \\
\text { Popolare Etica } \\
\text { (Fiare) } \\
\text { www.fiareban } \\
\text { caetica.coop } \\
\end{array}$ \\
\hline $\begin{array}{l}\text { Type of } \\
\text { bank }\end{array}$ & $\begin{array}{l}\text { Traditional } \\
\text { Bank }\end{array}$ & $\begin{array}{l}\text { Traditional } \\
\text { Bank }\end{array}$ & Ethic bank & Ethic bank \\
\hline $\begin{array}{l}\text { Rankin } \\
\text { g by } \\
\text { assets }\end{array}$ & $\begin{array}{l}1 \text { (Spain) } \\
18 \\
\text { (Global) }\end{array}$ & $\begin{array}{l}2 \text { (Spain) } \\
46 \\
\text { (Global) }\end{array}$ & $\begin{array}{l}21 \\
\text { (Netherlan } \\
\text { ds) } \\
1,481 \\
\text { (Global) }\end{array}$ & $\begin{array}{l}168 \text { (Italy) } \\
\text { 3,948 (Global) }\end{array}$ \\
\hline $\begin{array}{l}\text { Total } \\
\text { Assets } \\
\text { (miles } \\
\text { USD) }\end{array}$ & $\begin{array}{l}1,537,326, \\
651(2014)\end{array}$ & $\begin{array}{l}767,199,2 \\
00(2014)\end{array}$ & $\begin{array}{l}8,890,774 \\
(2012)\end{array}$ & $\begin{array}{l}1,519,652 \\
(2012)\end{array}$ \\
\hline $\begin{array}{l}\text { Employ } \\
\text { ees }\end{array}$ & 185,405 & 108,770 & 1,017 & 210 \\
\hline Loans & $\begin{array}{l}\text { 734,711 } \\
\text { million } €\end{array}$ & $\begin{array}{l}330,686 \\
\text { million } €\end{array}$ & $\begin{array}{l}722 \\
\text { million } €\end{array}$ & $\begin{array}{l}816 \text { million } € \\
(2015)\end{array}$ \\
\hline $\begin{array}{l}\text { Invest } \\
\text { ment in } \\
\text { commu } \\
\text { nities }\end{array}$ & $\begin{array}{l}187 \\
\text { million } €\end{array}$ & $\begin{array}{l}107.2 \\
\text { million } €\end{array}$ & - & - \\
\hline
\end{tabular}

Source: Bankscope and corporate websites (Santander and BBVA, 2014; Tridos Bank and Fiare, 2012)

After 15 years working in Italy, the experience of Banca Popolare Etica - a cooperative bank of reference in Europe -, has given way to Fiare Banca Ética in Spain. The credit policy supports their partner organizations developing activities in the following areas of support: international cooperation and fair trade, social economic and inclusion, agroecology and renewable energy, and transforming social and cultural values. Triodos Bank is an independent European bank founded in 1980 - in Spain since 2004 -, based on ethical and sustainable banking. It develops a banking business model based on transparency and combines financial profitability with social and environmental returns. Over a century of history, Santander's mission is to contribute to the progress of individuals and businesses. It remained the largest bank in the Eurozone in 2014 and operates in 10 main markets. In Spain, there are 12.6 million customers and 24,979 employees. BBVA is a global financial group founded in 1857 with a focus on the customer. It operates in 31 countries and in Spain and Portugal, it has 29,308 employees.

\section{Results and discussion}

Results are presented following the structure of the theoretical section, considering those elements described in Table 3.

\section{Issuer}

The aims of ethical banking "go beyond economic benefits to include social objectives, assuming that both are relevant in a socio-economic model" (San-Jose et al. 2011: 151). Otherwise, traditional banks incorporate social aspects through their CSR policies, and especially, through their Socially Responsible Investments (SRI). Fiare Banca Ética "wants to be a tool for social transformation, through financing projects of solidarity economy and promoting a culture of financial intermediation under the principles of transparency, participation, democracy and the right of access to credit" (Fiare, 2015). Its Code of Ethics states that one of its values is transparency, as a style that characterizes communication between Ethical Banking and its stakeholders.

One of the corporate values of Triodos Bank is transparency, and it states that "we are transparent with the use of money, so that customers know the companies and projects we finance with their savings and investments and they become partakers of change we promote with their money". Santander's mission is to contribute to the development of people and companies and its vision is "to be the best commercial bank, earning the trust and loyalty of our employees, customers, shareholders and society (...) maintaining relationships with our suppliers based on ethics, transparency and mutual respect" (Santander 2015). BBVA's mission is "to offer the best solutions and financial services to our customers and its vision is to work for a better future for people". BBVA determines that it performs responsible banking as a permanent commitment to strengthen the social role of the Group and regain society (...) based on the principles of integrity, prudence, and transparency (BBVA 2014).

While traditional commercial banks rely on principles of transparency as a complement to their mission and vision, ethical banks in the sample consider transparency as reflected in corporate values. Noteworthy is the concept of regaining society reviewed by BBVA, which implicitly recognizes the existence of a gap between traditional banking and society, intended to be shortened. Polyphony noted by Schoeneborn and Trittin (2013) can be identified in traditional banks because, although they implement a CSR policy and offer SRI, there may not be a clear convergence of their major interests. In ethical banking, harmony appears to be greater.

\section{Channel}

Although the channel of communication is the great forgotten when dealing with transparency (Baraibar \& Luna 2012), the fact is that it is one of the keys in order to reach the appropriate receiver and businesses consider it more and more importantly. Regarding ESG information, CSR or sustainability reports, corporate websites, and magazines are the most widespread, but nowadays, banks are using a wide variety of channels to reach stakeholders. Santander and BBVA reports describe the tools they use within the dialogue with each group of interest independently (notwithstanding other channels identified in the analysis). Fiare and Triodos Bank are not so specific. Tables 5 to 8 show generic channels used by each bank in the sample broken into groups of stakeholders.

Table 5: Channels of information used by Fiare with each stakeholder

\begin{tabular}{|l|l|}
\hline Stakeholder & Channel of information \\
\hline Generic & $\begin{array}{l}\text { Corporate website, Social balance website, Blog, } \\
\text { Newsletter, RSS, Email, Twitter, Facebook, } \\
\text { Territory initiative groups (email), Contact form }\end{array}$ \\
\hline Customers & $\begin{array}{l}\text { Online banking, Office, Blog, Newsletter, Twitter, } \\
\text { Facebook, Territory initiative groups (email), } \\
\text { Contact form }\end{array}$ \\
\hline Partners & $\begin{array}{l}\text { Events, Training days, Partners assembly, Area } \\
\text { forums, Interforum, Networks }\end{array}$ \\
\hline
\end{tabular}

Note: Fiare doesn't describe channels of communication group by group and those identified have been identified by analyzing the website.

Source: Fiare website. 
Table 6: Channels of information used by Triodos Bank with each stakeholder

\begin{tabular}{|c|c|}
\hline Stakeholder & Channel of information \\
\hline Generic & $\begin{array}{l}\text { Corporate website, Corporate magazine (Revista } \\
\text { Triodos), Triodos } 2.0 \text { community (Facebook, } \\
\text { Twitter, YouTube, LinkedIn, Google, Pinterest), } \\
\text { Telephone number, Email, Offices, Blogs (Somos } \\
\text { Triodos, Dinero y Conciencia), Contact form, FAQ, } \\
\text { Forms, Project browser }\end{array}$ \\
\hline Customers & $\begin{array}{l}\text { Office, Customer service, Internet banking, } \\
\text { Telephone banking, Post banking, }\end{array}$ \\
\hline Investors & General Assembly \\
\hline Society & $\begin{array}{l}\text { Press area, Email, Telephone, Press dossier; } \\
\text { Conferences }\end{array}$ \\
\hline
\end{tabular}

Source: Triodos bank website.

Table 7. Channels of information used by Santander with each stakeholder.

\begin{tabular}{|l|l|}
\hline Stakeholder & Channel of information \\
\hline Generic & $\begin{array}{l}\text { Corporate website, Annual Report, Sustainability } \\
\text { Report, Social media profiles } 1 \text {, Press Room (press } \\
\text { releases, news, reports, results presentation, } \\
\text { pictures, videos, audio), }\end{array}$ \\
\hline Employees & $\begin{array}{l}\text { Global commitment survey, Santander Ideas, } \\
\text { Santander news (Corporate Intranet), Managers } \\
\text { portal, local intranets, whistleblower channel }\end{array}$ \\
\hline Suppliers & $\begin{array}{l}\text { Suppliers portal, negotiation processes, suppliers } \\
\text { polled, Suppliers box, Forum, Interviews, } \\
\text { Aquanima. }\end{array}$ \\
\hline
\end{tabular}

Customers

Branches, website, Online Banking, Telephone Banking, Smartphone banking, Cashier, Surveys, Customer service: telephone, twitter, email).

Shareholders

General Shareholders Meeting, Shareholder Service Centers, Shareholder hotlines,

Shareholder helpline, Shareholder mailbox, Mailing list, Newsletters, FAQs, SMS alert service, Santander Shareholders App,

Shareholders' website

(www.yosoyaccionista.santander.com), Telephone

\begin{tabular}{l|l} 
Communities & Corporate website, social networks \\
\hline Investors & $\begin{array}{l}\text { Reports, result presentations, financial reports, } \\
\text { mailing lists }\end{array}$ \\
\hline
\end{tabular}

Note: ${ }^{1} 60$ profiles on Facebook (5,532,512 followers), LinkedIn, Tuenti in Spain, 48 profiles on Twitter (742,613 followers), 39 channels in YouTube (

Source: Santander 5,896 videos and 108,216,029 views), and 15 profiles on Google $+(150,959$ followers $)$ and 2 profiles on Pinterest (1,441 followers) 2014 Sustainability report and Santander corporate website
Table 8: Channels of information used by BBVA with each stakeholder

\begin{tabular}{|c|c|}
\hline Stakeholder & Channel of information \\
\hline Generic & $\begin{array}{l}\text { Corporate website, Responsible banking website, } \\
\text { local websites, social media website (Facebook, } \\
\text { Twitter, YouTube, Google+, LinkedIn), blog, }\end{array}$ \\
\hline $\begin{array}{l}\text { Society and } \\
\text { customers }\end{array}$ & $\begin{array}{l}\text { Customer Experience Areas (surveys), Customer } \\
\text { Service and Complaint and Claims Analysis } \\
\text { Committees, Customer Ombudsman, External } \\
\text { Reputation Survey of Customers and Society in } \\
\text { general (reptrak), Focus groups and work days } \\
\text { with customers, Social networks, Direct Dialogue } \\
\text { with NGOs, the media, experts and academic and } \\
\text { research centers, Corporate Responsibility and } \\
\text { Reputation events and forums, Communication \& } \\
\text { Brand and Corporate Responsibility and } \\
\text { Reputation Departments }\end{array}$ \\
\hline Employees & $\begin{array}{l}\text { Employee Service, Annual employee satisfaction } \\
\text { survey, Annual internal reputation survey for } \\
\text { employees, Oracle for regular listening to } \\
\text { employees, Focus groups and work days with } \\
\text { employees, Regular personal interviews between } \\
\text { managers and their team members, Breakfast with } \\
\text { management, Employee portal (Tu\&BBVA), } \\
\text { Websites for dialogue on specific issues (Genera } \\
\text { website about WLB practices), Code of Conduct } \\
\text { mailbox, Mass meetings and events (meetings with } \\
\text { managers, area days, etc.), HR department, } \\
\text { Discussion with employees' representatives. }\end{array}$ \\
\hline $\begin{array}{l}\text { Shareholders } \\
\text { and investors }\end{array}$ & $\begin{array}{l}\text { General Shareholders Meeting, Website for } \\
\text { shareholders and investors, Annual and quarterly } \\
\text { reports and significant events, Constant contact } \\
\text { (email and telephone helplines, events in branches, } \\
\text { etc.), Roadshows and meetings, Attendance at } \\
\text { conferences, Communication with analysts and } \\
\text { rating agencies, Alert services and distribution of } \\
\text { relevant information, Appdate, Press room, } \\
\text { Shareholder Club (Ábaco Magazine, Ábaco Club, } \\
\text { Contents) }\end{array}$ \\
\hline Regulators & $\begin{array}{l}\text { Institutional relations: formal and informal forums, } \\
\text { Departments involved in managing relations with } \\
\text { regulators: General Secretary, Legal Services, } \\
\text { Institutional Relations, Internal Control, Risks, } \\
\text { Chairman's Office, Reports on regulatory trends }\end{array}$ \\
\hline Suppliers & $\begin{array}{l}\text { Approval questionnaires, Satisfaction surveys, } \\
\text { Regular meetings, Online negotiation and } \\
\text { procurement tool, Procurement department. }\end{array}$ \\
\hline
\end{tabular}

Note: Channels have been extracted from the section Dialogue with stakeholders and materiality analysis

Source: BBVA Responsible Banking Report 2014 and BBVA corporate website.

Analysis of channels of communication is difficult as ESG information is not specifically disclosed in only one channel of information. The perception is that in ethical banks, all channels are mostly devoted to 
disclosing ESG information (as in their own nature) and the traditional commercial banks have specific channels to disclose that type of information (a specific section of the corporate website or the sustainability reports). In those banks, special attention is paid to relationships with shareholders.

\section{Message}

Communicating CSR is becoming increasingly important as "those activities may influence opinion leader's behaviors regarding a target organization" (APCO 2004, cited by Birth et al. 2008). As we said before, content and volume of information give way to other features of information such as materiality, timeliness, reliability of the information or the way information is presented. Table 9 shows different characteristics of CSR information in the banks in the sample.

BBVA and Fiare present a social balance on their websites and both include quantitative information broken down by stakeholders. Although Santander and Triodos Bank don't have an implicit social balance, they all try to show their CSR commitment focusing on the output side of their CSR endeavor and as Du et al. (2010) noticed, focusing on their CSR impact.

San-Jose et al. (2011: 153), citing Cowton and Thompson (1999) and Cowton (2010), state that "ethical banks provide an unusually high level of transparency and more detailed information to their depositors with regard to where money has been lent - information transparency and placement of assets - and how ethical banking policy is based on the assumption of risk conditions associated with improvements in terms of asset allocation - alternative guarantee systems".

Triodos Bank has created a pioneer online tool to present projects and companies financed by the savings of their customers (Stories of transparent banking). Much less detailed, it is also possible to know some of the financed projects in Fiare (With my money). In traditional banking, this idea of ending use is equivalent to the concepts of screening or negative/exclusion criteria in socially responsible investment (SRI) - you don't know in which companies you invest, but you know the avoidance of companies due to some reasons -.

Analysis of materiality is related to CSR motives and especially to significant issues that affect their stakeholders. Excepting Fiare, the other banks in the sample develop a materiality study that identifies key issues for each group of interest. Regarding timeliness, the nature of the concept hinders rigor (timeliness for what and for who?) but we must say that Santander, BBVA and Triodos corporate websites include dates and updates that allow knowing the timing of information disclosure.

Finally, reliability of information can be authorized by sustainability ratings or information verification processes. Santander, BBVA and Triodos develop CSR information regarding GRI guidelines and independently assured, whereas Fiare is certified by the Italian Institute for Ethical and Environmental Certification.

\section{Receiver}

Identifying target groups is a basic issue in communication (Berceruelo et al. 2013) and the four banks show that dialogue with groups of interest is important for them. Table 10 shows the groups of interest described by each bank in the sample.
Table 9: Features of information

\begin{tabular}{|c|c|c|c|}
\hline Bank & $\begin{array}{l}\begin{array}{l}\text { Social } \\
\text { balance }\end{array} \\
\end{array}$ & Materiality & $\begin{array}{l}\text { CSR standards - } \\
\text { Reliability }\end{array}$ \\
\hline Santander & No & $\begin{array}{l}\text { Materiality } \\
\text { study: matrix } \\
\text { of material } \\
\text { concerns. }\end{array}$ & $\begin{array}{l}\text { Independent Assurance } \\
\text { Report on the } 2014 \\
\text { Sustainability Report of } \\
\text { the Santander Group by } \\
\text { Deloitte (GRI G4, } \\
\text { AccountAbility's } \\
\text { AA1000 Accountability } \\
\text { Principles Standard } \\
2008 \text { (AA1000APS)) }\end{array}$ \\
\hline BBVA & Yes & $\begin{array}{l}\text { Materiality } \\
\text { analysis, } \\
\text { Significant } \\
\text { issues } \\
\text { (affected } \\
\text { stakeholders, } \\
\text { scope, impact } \\
\text { and BBVA's } \\
\text { response) and } \\
\text { sensitive } \\
\text { issues. }\end{array}$ & $\begin{array}{l}\text { Independent Assurance } \\
\text { Report on the } 2014 \\
\text { Responsible Banking } \\
\text { Report of the BBVA } \\
\text { Group by Deloitte (GRI } \\
\text { G4, AccountAbility's } \\
\text { AA1000 Accountability } \\
\text { Principles Standard } \\
2008 \text { (AA1000APS)) }\end{array}$ \\
\hline $\begin{array}{l}\text { Triodos } \\
\text { Bank }\end{array}$ & No & $\begin{array}{l}\text { Materiality } \\
\text { matrix }\end{array}$ & $\begin{array}{l}\text { GRI Standards } \\
\text { Independent Auditor's } \\
\text { Assurance Report on the } \\
\text { Triodos online Annual } \\
\text { Report } 2014 \text { by KPMG } \\
\text { Accountants N.V. } \\
\text { (Dutch Standard 3000) }\end{array}$ \\
\hline Fiare & Yes & $\begin{array}{l}\text { No references } \\
\text { to materiality }\end{array}$ & $\begin{array}{l}\text { Social value (Valor } \\
\text { social) certification by } \\
\text { ICEA (Institute for } \\
\text { Ethical and } \\
\text { Environmental } \\
\text { Certification). }\end{array}$ \\
\hline
\end{tabular}

Source: BBVA Responsible Banking Report 2014, Santander 2014 Sustainability Report, Triodos website and Fiare website.

Fiare's Code of Ethics determines that the groups of interest are strictly members, savers, credit users, collaborators, suppliers, participatory institutions, partners in the project and in a broad sense the community and the institutions that represent it (public bodies, companies, civil society organizations, social actors) and all those who even indirectly are socially, environmentally and economically affected by the activity of the bank (beneficiaries of financial activities, local communities, future generations). Triodos Bank describes three main groups of interest in the annual report: "those that carry out economic transactions with the business, those that don't engage in economic transactions, but who maintain a close interest in Triodos Bank, and finally those that provide new insights and knowledge, prompting them to reflect, rethink and explore new territory" (2014 Annual Report).

Santander's corporate website and sustainability report describe who their stakeholders are: shareholders, customers, employees, suppliers, and society. BBVA's corporate website determines that the stakeholders are customers, employees, shareholders, suppliers and society in general. Responsible Banking Report 2014 describes that the dialogue with stakeholder is focused on society and customers, employees, shareholders and investors and regulators. 
Table 10: Identification of stakeholders

\begin{tabular}{|c|c|}
\hline Entity & Stakeholders \\
\hline Santander & $\begin{array}{l}\text { Employees, suppliers, customers, shareholders, } \\
\text { communities ( } 2014 \text { Sustainability Report) }\end{array}$ \\
\hline BBVA & $\begin{array}{l}\text { Customers, employees, shareholders, suppliers and } \\
\text { society (Corporate website). }\end{array}$ \\
\hline $\begin{array}{l}\text { Triodos } \\
\text { Bank }\end{array}$ & $\begin{array}{l}\text { Commercial stakeholders, who carry out economic } \\
\text { transactions (e.g., customers, depository receipt } \\
\text { holders, co-workers, and suppliers); non-commercial } \\
\text { stakeholders, but have social interests related to } \\
\text { Triodos Bank (eg NGOs, governments and the media); } \\
\text { and others that provide knowledge or innovations in } \\
\text { banking sector (e.g. advisors) (2014 Annual Report). }\end{array}$ \\
\hline Fiare & $\begin{array}{l}\text { Workers, shareholders, customers, consumers, } \\
\text { suppliers, creditors, local and national communities, } \\
\text { associations, public institutions and future generations } \\
\text { (Corporate website) }\end{array}$ \\
\hline
\end{tabular}

Source: Corporate websites and CSR reports.

Although traditional banking includes in corporate websites relationships with more agents than those explicitly called stakeholders, it is mainly focused on basic and traditional stakeholders: customers, employees, shareholders, suppliers and community/society. Ethical banking is more specific when describing its stakeholders, disaggregating the groups and in the case of Fiare, presenting the social balance for each group of interest.

\section{Conclusions}

"The combination of being conscious (commitment of the issuer) about knowing what it is important to say (materiality) to the one who is interested in listening (identification of stakeholders) and how to reach them properly (analysis of channels of information) is the key to transparency" (Baraibar et al., 2016). Assessing transparency is a very ambitious goal, but this exploratory study has identified how two traditional banks in Spain (Santander and BBVA) and two ethical banks (Triodos Bank and Fiare) deal with those elements of communication that are important to achieve transparency.

In this sense, ethical banking includes the term transparency within its corporate values and although traditional banks also follow the principle of transparency, it is not one of its main objectives. This may be one of the problems to achieve a transparent and effective CSR communication: whereas in ethical banking the harmony is evident, CSR in traditional banking could be perceived as not consonant with other organizational practices (for instance, traditional banking discloses investment in communities whereas analyzed ethical banks don't include a specific statement because all their investment focus on social issues). This issue is evident in the mission of BBVA, which implicitly recognizes a gap between traditional banking and society.

Regarding the channel of information, Santander and BBVA are much more explicit when describing their dialogue with their stakeholders and the resources and networks are higher than those described in ethical banking. As for the combination of channels of information and interests of stakeholders, it is important to remark the initiative developed by Triodos Bank (with the global annual report and not in the Spanish site), allowing stakeholders to create their own reports, by selecting the chapters they really want to read.

Both types of banking implement the "business case for CSR" (Carroll \& Shabana 2010) focusing on numbers and demands for profitability and communicating the importance of the core issues of their social actions previously gauged by a materiality study - in order to increase stakeholders' backing. The two traditional banks and Triodos Bank - not Fiare, maybe because it is just a project - use GRI guidelines to disclose information, which enhances credibility.
Morsing and Schultz (2006) determine that managers need to move from communications strategies related to "informing" and "responding" to communication strategies related to "involving" stakeholders in CSR communication itself. Ethical banks are winning the career of involvement since deposits in Triodos Bank and Fiare have increased more than $20 \%$ in the last year, while Santander and BBVA have a negative growth. In addition to defining stakeholders in a broader sense, one of the most groundbreaking initiatives is to make public the projects - even through the protagonists themselves - to which the money invested by customers is targeted (Story of transparent banking and With my money). Customers can even decide at the beginning which type of project they want to invest in. In this sense, ethical bank users are supposed to be more concerned about CSR issues and are proactive to support those types of activities so that effectiveness of CSR communication will be higher. They even act as CSR activists (Dawkins 2004, cited by Du et al. 2010) "who are more likely to purchase on ethical criteria, be more aware of companies' CSR activities, and more likely to investigate companies' CSR behavior".

One of the main limitations of this contribution is the scope of the study. There are striking differences among four considered banks in size and available resources - Fiare is a still a project which is being implemented in Spain -, what would have led to a very risky and biased quantitative comparison. For this reason, an exploratory study has been performed and has led to the identification of good transparent practices (Stories of transparent banking, Create your own report, With my money) but also to raise several issues for future research: is goodwill enough to achieve a transparent CSR communication strategy? Can an initiative like Fiare be on the same level than Santander, with such a level of resources to materialize relationships with stakeholders? Besides, as a final conclusion, we can say that resources are important but also beliefs, and the perception is that traditional banks produce communication and ethical banks are communication. Ethical banks operate within transparency, while traditional banks simply consider principles of transparency. Ethical banks have a strong commitment to their ethical code, corporate social responsibility, and transparency. These values are supposed to increase the effectiveness of communication since the audience supports all these initiatives.

\section{References}

- APCO (2004). Communicating CSR: talking to people who listen, Global CSR Study, available at: www.apcoworldwide.com (accessed May 2015)

- Ashcraft, K.L., Kuhn, T.R. \& Cooren, F. (2009). "Constitutional amendments: 'materializing' organizational communication", Academy of Management Annals, 3(1), 1-64, CrossRef

- $\quad$ Baraibar-Diez, E.,\& Luna, L. (2012).Transparencia social e hipótesis del impacto social: análisis en el IBEX35, Universia Business Review, 36, 108-123.

- Baraibar-Diez, E. and Odriozola, M. (2015). "Transparency and communication: Kipling's six questions", Mediterranean Journal of Communication, 6(2), 83-97.

- $\quad$ Baraibar-Diez, E.; Odriozola M. D. \& Fernandez-Sánchez J. L. (June 2016). How do new business models in banking approach stakeholders? In International Conference New Business Models - Exploring a changing view on organizing value creation. Toulouse Business School.

- Berceruelo, B. (Ed.) (2013).Comunicación financiera: Transparencia y confianza. Estudios \& Investigación. Estudio de comunicación.

- Birth, G., Illia, L., Lurati, F. \& Zamparini, A. (2008).Communicating CSR: practices among Switzerland's 
top 300 companies, Corporate Communications: An International Journal, 13(2), 182-196.

- Carroll, A. B. (1999). Corporate social responsibility: evolution of a definitional construct, Business and Society, 38(3), 268296, CrossRef

- Carroll, A. B. \& Shabana, K. M. (2010). The business case for corporate social responsibility: a review of concepts, research and practice, International Journal of Management Review, 12(1), 85-91, CrossRef

- Clarkson, M. B .E. (1995). A Stakeholder Framework for Analyzing and Evaluating Corporate Social Performance, Academy of Management Review, 20(1), 92-117, CrossRef

- Cortés García, F.J. (2003).Caracterización del sector bancario en España. Boletín económico del ICE, Información Comercial Española, 2753,17-22.

- Cowton, C. (2002).Integrity, Responsibility and Affinity: Three aspects of Ethics in Banking. Business Ethics: A European Review, 11(4), 393-400, CrossRef

- Cowton, C. (2010).Banking, in J. Boatright (ed.) Finance Ethics: Critical Issues in Financial Theory and Practice (Kolb Series in Finance, Wiley, NJ).

- CSR Europe (2000a).The First Ever European Survey of Consumers' Attitude on Corporate Social Responsibility, CSR Europe Publications, Brussels.

- CSR Europe (2000b). Communicating Corporate Social Responsibility, CSR Europe Publications, Brussels.

- Dawkins, J. (2004). Corporate responsibility: the communication challenge. Journal of Communication Challenge, 9, 108-119.

- $\quad$ De la Cuesta, M.; Fernández, B. and Vázquez, O. (2006).Razón de ser de la Banca Ética. Experiencias internacionales y nacionales. Ensayos de la Fundación de las Cajas de Ahorros (FUNCAS).

- $\quad$ Du, S., Bhattacharya, C.B. and Sen, S. (2010). "Maximizing Business Returns to Corporate Social Responsibility (CSR): The Role of CSR Communication", International Journal of Management Reviews, doi: 10.1111/j.14682370.2009.00276.x, CrossRef

- febea (2012).What really differentiates ethical banks from modern banks? European Federation of Ethical and Alternative Banks and Financiers.

- febea (2015). European Federation of Ethical and Alternative Banks website. www.febea.org (accessed May 2015)

- $\quad$ Freeman, R.E. and McVea, J.A. (2001).A stakeholder approach to strategic management. Darden Business School Working Paper no. 01-02, CrossRef

- GABV (2014). Real economy - Real returns: The Business Case for Sustainability Focused Banking. Available at http://www.gabv.org/wp-content/uploads/Real-EconomyReal-Returns-GABV-Research-2014.pdf (accessed May 2015).

- $\quad$ GABV (2015). Global Alliance for Banking on Values website. www.gabv.org (accessed May 2015)

- Gutiérrez García, E.\& Sádaba Garraza, T. (2010).Making things happen: the role of communication in strategic management. A case study on banking industry. Comunicación y Sociedad, XXIII(2), 179-201.

- Jackson, C. (2012).Made in heaven or marriage from hell? Social media and the financial sector. Financial Sector Communications, Cicero Consulting.
- Kaptein, M. \& Van Tulder, R. (2003).Toward effective stakeholder dialogue. Business and Society Review, 108, 203225, CrossRef

- KPMG (2013).International Survey of Corporate Responsibility Reporting, Available at http://www.kpmg.com/Global/en/IssuesAndInsights/ArticlesP ublications/corporate-responsibility/Documents/corporateresponsibility-reporting-survey-2013-v2.pdf (accessed May 2015).

- $\quad$ Mitchell, R.K., Agle, B. R. \& Wood, D. J. (1997). Toward a theory of stakeholder identification and salience: Defining the principle of who and what really counts. Academy of Management Review, 22(4), 853-886, CrossRef

- Morsing, M. \& Schultz, M. (2006). Corporate social responsibility communication: stakeholder information, response and involvement strategies. Business Ethics: A European Review, 15, 323-338, CrossRef

- Nargundkar, R. (2003).Marketing Research: Text and Cases, 2nd Ed. Tata McGraw Hill

- $\quad$ Romney, A.K., Weller, S. C., \& Batchelder, W. C. (1986). Culture as consensus: a theory of culture and informant accuracy. American Anthropologist,88(2), 313-338, CrossRef

- $\quad$ San-Jose, L. \& Retolaza, J.L. (2008).Information transparency as Differentiation Factor of Ethical Banking in Europe: Radical Affinity Index Approach. The ICFAI Journal of Bank Management, 7(3), 7-22, CrossRef

- $\quad$ San-Jose, L.; Retolaza, J.L. \& Gutierrez-Goiria, J. (2011). Are Ethical Banks Different? A Comparative Analysis Using the Radical Affinity Index. Journal of Business Ethics, 100, 151173

- Schoeneborn, D. \& Trittin, H. (2013). Transcending transmission. Towards a constitutive perspective on CSR communication. Corporate Communications: An International Journal. 18(2), 193-211, CrossRef

- Schrenk, L.P. (2006). Equityholder versus Stakeholder and Corporate Governance: Developing a Market for Morality, Business Renaissance Quarterly, 1(3).

- Stebbins, R.A. (2001). Exploratory Research in the Social Sciences. Sage University Papers Series on Qualitative Research Methods, Vol. 48. Thousand Oaks, CA: Sage, CrossRef

- $\quad$ Trotter, R.T. (2012). Qualitative research sample design and sample size: Resolving and unresolved issues and inferential imperatives. Preventive Medicine, 55, 398-400, CrossRef

- Zerfass, A. \& Huck, S. (2007). Innovation, Communication, and Leadership: New Developments in Strategic Communication, International Journal of Strategic Communication, 1(2), 107-122, CrossRef

- Zorio, A., García-Benau, M.A. \& Sierra, L. (2012).Sustainability Development and the Quality of Assurance Reports: Empirical Evidence. Business Strategy and the Environment, 22(7), 484-500, CrossRef 